\title{
Analysis of energy usage and cost management of mechanize grabber in oil palm plantation
}

\author{
Yusop, M.I.M. and ${ }^{*}$ Mustaffha, S. \\ Faculty of Plantation and Agrotechnology, Universiti Teknologi Mara Malaysia, Cawangan Melaka \\ Kampus Jasin, 77300 Merlimau, Melaka, Malaysia
}

\author{
Article history: \\ Received: 22 July 2020 \\ Received in revised form: 5 \\ December 2020 \\ Accepted: 16 December 2020 \\ Available Online: 20 \\ December 2020
}

Keywords:

Fresh fruit bunch (FFB),

Energy consumption,

Field capacity,

Total operation cost,

Tractor grabber

DOI:

https://doi.org/10.26656/fr.2017.4(S5).001

\begin{abstract}
The aim of this study was to evaluate the energy usage and total operation cost of the tractor grabber. The data was collected at FELCRA BERHAD Kawasan Titi Gantong, Bota, Perak. The total cost included all the operation in loading system and evacuation process of fresh fruit bunch (FFB). This study evaluated the energy usage of tractor grabber for three consecutive months using a newly purchased Mini Tractor Grabber Kubota L4400. This study was conducted based on the energy input-output methodology. Mathematical equations are used to determine the field capacity and examine energy usage. The result found that $153.38 \mathrm{MJha}^{-1}$ of input energy was required to produce 328.43 metric ton per month of FFB in June. The energy was dominated by fuel consumption, machinery and followed by labour. The total operating cost is based on the field capacity of the machine. This study was conducted and obtained the result, assumed that the total cost for a year is RM 47,444.24 and the cost per metric ton is RM 9.76 with energy consumption of $174.23 \mathrm{MJ}$. Conclusively, it means that the energy usage and cost of operation is efficiently and effectively used in oil palm productivity in FELCRA BERHAD Kawasan Titi Gantong.
\end{abstract}

\section{Introduction}

Nowadays plantation industry especially in oil palm sectors has been facing several issues especially in the yield quality and also in the financial problems. The decrease of the quality of the fruit will affect the oil palm extraction (OER) process and can also affect the price of the crude palm oil (CPO). The main factor of this issue is the late evacuation of the fresh fruit bunch (FFB) to the mill. Malaysian Palm Oil Board has standardized that $5 \%$ of free fatty acid (FFA) production due to lack of transportation from field to mill (MPOB, 2014).

Oil palm field operation consists of several tasks such as loading the FFB, evacuating the FFB and other jobs. Most of the operations require a lot of energy from labourers (Azwan et al., 2015). According to Ismail et al. (2013), labourers who work as harvesters and collectors are the highest, accounting for $40 \%$ of the total workers in the plantation sector since it is the most intensive process. Therefore, the implementation of mechanization is a must in order to reduce the dependency of labour in the oil palm operations in plantation (Adib and Pebrian, 2018). Although the implementation of mechanization in Malaysian plantation has started since the 1960 s, it was only used in certain operations (Azwan et al., 2015). Among mechanizations which mostly used in the in-field operations are a wheelbarrow, mini tractor, eco rider, buffalo and grabber (Awaludin, 2011).

Field capacity and field efficiency are the primary parameters used to identify the performance of the machine which can later be used to determine the machine operating cost. Among the most important cost that influences the final profit in plantation operation is the cost of operating machinery. Normally, machines operate using diesel as fuel which is then converted into mechanical energy to perform jobs. Hence, it is very crucial to manage the machines in order to reduce unnecessary fuel burning to maximize productivity and at the same time leaving less impact on the environment (Bartzas and Komnitsas, 2018).

Many studies have been conducted to evaluate the energy used and its cost analysis in other agricultural productions (Baran and Gokdogan, 2016; Biswas, 2017; Sharifi, 2018; Bartzas and Komnitsas, 2018; Noor et al., 2020). The energy used can be classified into direct sources like fuel, labour, animal power, fertilizers and chemicals and indirect sources like input energy required 
in a machine production (Azwan et al., 2015). The use of incorrect input energy and field capacity of a machine can lead to excessive energy usage which causes an increase in the production cost of a plantation. The cost is predicted based on the amount of fuel and other resources consumed which are directly related to the amount of energy exerted.

Therefore, the aims of this study are to evaluate the field capacity and the energy usage in oil palm plantation operations, especially fuel consumption in mechanize grabber operation. This study utilizes the energy of input, output, specific and net energy in the mechanize grabber operation based on daily operation for three consecutive months. Then, the result can be used to calculate the operating cost. Thus, a more efficient manner of energy utilization can be determined and initiated for financial saving or environmental benefits.

\section{Materials and methods}

\subsection{Data collection}

In data collection, energy analysis methodology introduced by Fluck (1991) was used in this study. The first step was to determine the boundary or area of the study. While the next step is to determine and estimate the input and output from the selected area. Third and fourth steps include converting all input and output data into an energy unit. The final result produced is the indication of energy operation and performance through energy indices obtained from the analysis.

The study was carried out in plantation of FELCRA Berhad Kawasan Titi Gantong, Bota, Perak Malaysia with coverage area about 1527.57 ha with 14 plots. However, in this study, one plot of 186.45 ha was used to test the machine grabber for daily operation. The machine used was a newly purchased Mini Tractor Grabber Kubota L4400. The data taken based on a daily operation which consists of working hour per day, the capacity of the tractor grabber, fuel consumption, cost of the maintenances per month and the yields per month from the mechanize grabber. The data was recorded for three consecutive months since the company bought the machinery.

\subsection{Calculation}

\subsubsection{Measuring field capacity}

Field capacity is usually shown in hectare or acre per hour. It is commonly used to measure machine capacity. Harvesting and evacuation process operations may be measured as tons per hour. The measurement of capacity includes the theoretical field capacity (TFC), effective field capacity (EFC) and material capacity (MC). Below are the formulas that has been used.

$$
\begin{aligned}
& \text { Field capacity }=\frac{\text { area }}{\text { time }} \\
& \text { Theoretical Field capacity }=\frac{\operatorname{speed}\left(\frac{\mathrm{km}}{\text { hour }}\right) \times \text { trailer capacity }(\mathrm{mt})}{10} \\
& \text { Effective field capacity, }(\mathrm{ha} / \mathrm{hr})=\frac{\text { yield }(\mathrm{mt})}{\text { time }(\mathrm{hr})} \\
& \text { Field efficiency, }(\%)=\frac{\text { Effective field capacity }}{\text { Theoretical Field capacity }} \times 100 \\
& \text { Effective material capacity, }(\mathrm{mt} / \mathrm{hr})=\frac{\text { Weight }(\mathrm{mt})}{\text { Time (hour })}
\end{aligned}
$$

\subsubsection{Estimating fuel and repair cost}

Estimating fuel and repair cost is possible because the amount of fuel consumed is directly related to the amount of energy exerted.

Average Fuel consumption $=$ Horsepower $(\mathrm{Hp}) \times 0.233$ (for diesel)

Average Fuel Cost $=$ Fuel consumption $\times$ Price of diesel

Average Fuel and Lubricant Cost $=$ Fuel cost $+(10 \% \times$ Fuel cost $)$

The estimation of repair cost be determining with using this equation;

$\mathrm{TAR}=$ List Price $\mathrm{x}$ RF1 $\mathrm{x}(\text { hours } / 1,000)^{\mathrm{RF} 2}$

Where TAR $=$ Total Accumulated Repairs, RF1 and $\mathrm{RF} 2=$ repair factors.

\subsubsection{Energy calculation}

The energy was calculated based on the obtained input, multiplied with the coefficient of energy equivalent to previous research literature. The unit of the result was in MegaJoule (MJ) per hectare term. The energy contributed by the machine can be calculated with the equation (Moerschner and Gerowitt, 2000).

$\mathrm{ME}=(\mathrm{G} \times \mathrm{E}) /(\mathrm{T} \times \mathrm{C})$

Where $\mathrm{ME}=$ machine energy $(\mathrm{MJ} / \mathrm{ha}), \mathrm{G}=$ weight of the tractor $(\mathrm{kg}), \mathrm{E}=$ constant $(41.4 \mathrm{MJ} / \mathrm{kg}), \mathrm{T}=$ economic life of tractor and $\mathrm{C}=$ effective field capacity

The energy ratio (energy use efficiency) and energy productivity were calculated as follows (Singh et al., 1997) and (Mandal et al., 2002) respectively below:

$$
\begin{aligned}
& \text { Energy use efficiency }=\frac{\text { Energy output }\left(M J h a^{-1}\right)}{\text { Energy input }\left(M J h a^{-1}\right)} \\
& \text { Energy productivity }=\frac{\text { Fresh fruit bunch output }\left(\mathrm{kgha}^{-1}\right)}{\text { Energy input }\left(M J h a^{-1}\right)}
\end{aligned}
$$

The value of the energy ratio more than 1 indicates that the production is using energy efficiently, whereas if the energy ratio is less than 1 , it can be concluded that the method is not feasible in an energy review (Haryanto et al., 2018).

\section{Results and discussion}

The data that was collected from the plantation for 
Table 1. Productivity of tractor grabber (Kubota 14400) for three months

\begin{tabular}{ccccccccccc}
\hline Month & Field area & $\begin{array}{c}\text { Harvesting Area cover } \\
\text { round }\end{array}$ & $\begin{array}{c}\text { Working } \\
\text { (ha) }\end{array}$ & $\begin{array}{c}\text { Working/month } \\
\text { day (hr) }\end{array}$ & $\begin{array}{c}\text { Working } \\
\text { area/day } \\
\text { (ha) }\end{array}$ & $\begin{array}{c}\text { Yield/ } \\
\text { month (mt) }\end{array}$ & $\begin{array}{c}\text { Bunch } \\
\text { amount }\end{array}$ & $\begin{array}{c}\text { Fruit } \\
\text { bunch } \\
\text { average } \\
\text { (kg) }\end{array}$ & $\begin{array}{c}\text { Yield/day } \\
\text { (mt) }\end{array}$ \\
\hline June & 186.45 & 2 & 372.9 & 20 & 7 & 18.65 & 328.43 & 15,366 & 21.37 & 16.42 \\
July & 186.45 & 2 & 372.9 & 29 & 7 & 12.86 & 485.19 & 21,992 & 22.06 & 16.73 \\
August & 186.45 & 2 & 372.9 & 25 & 7 & 14.92 & 401.31 & 17745 & 22.62 & 16.05 \\
\hline
\end{tabular}

three months are shown in Table 1. Based on Table 1, it displays the information or details of the data for the tractor grabber operation for the three consecutive months. It shows the yield of the oil palm in that field based on month and day of the yield and the productivity of the tractor grabber towards the yield.

To evaluate the full field capacity of the tractor grabber, the effective field capacity (EFC) must be determined. EFC is the calculation to measure the area of the coverage of tractor grabber operations and the hours of the operation. EFC determines the actual operating capacity of the tractor in the field. The calculation EFC was calculated using Equation 3 and as seen in Table 2.

Table 2. Effective field capacity for the three months

\begin{tabular}{cccc}
\hline Month & $\begin{array}{c}\text { Yield/day } \\
(\mathrm{mt})\end{array}$ & $\begin{array}{c}\text { Working hours/day } \\
\text { (hour) }\end{array}$ & $\begin{array}{c}\text { EFC } \\
\text { (mt/hour) }\end{array}$ \\
\hline June & 16.42 & 7 & 2.36 \\
July & 16.73 & 7 & 2.39 \\
August & 16.05 & 7 & 2.3 \\
\hline
\end{tabular}

Field efficiency (FE) is to define the percentage of the machine operates and it is between the ratios of EFC with the TFC. Table 3 shows the percentage of the FE of the tractor grabber operation. The differences between the EFC and the TFC of the tractor grabber are shown in Figure 1. The EFC values of the three months were varied because of the working day and the working area for each month are different and the quantity of the FFB was distinctive as well in a specific month.

Table 3. Field efficiency for three months

\begin{tabular}{cccc}
\hline Month & EFC (mt/hour) & TFC (mt/hour) & FE (\%) \\
\hline June & 2.36 & 3.0 & 78.67 \\
July & 2.39 & 3.0 & 79.67 \\
August & 2.30 & 3.0 & 76.67 \\
\hline
\end{tabular}

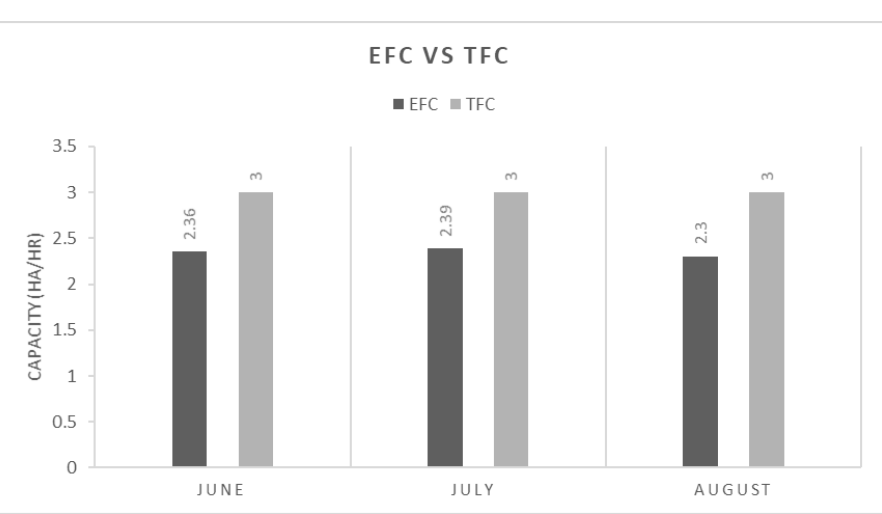

Figure 1. Field capacity during each month of operation eISSN: $2550-2166$
The total cost can be used to estimate the costs involved in the tractor grabber operation including the labour cost, fuel consumption cost and repair and maintenance cost. The total cost was calculated to show the estimation of the total cost for tractor grabber for three months to observe results on whether the company is overspending based on the yield that the company achieved for the month. Hence, Table 4 shows the total cost of the operation using the tractor grabber for three months.

Cost / metric ton $=$ RM 11,861.06 / 1,214.93 metric ton $($ *yield for 3 month $)=$ RM9.76/metric ton

\begin{tabular}{lc}
\multicolumn{2}{l}{ Table 4. Total cost for three months } \\
\hline Cost description & Total cost (RM) \\
\hline Fuel and lubricant & 8485.19 \\
Labour & 3128.72 \\
Repair and maintenance & 247.15 \\
\hline
\end{tabular}

The total cost for the tractor grabber for the three months was RM $11,861.06$. That means the company did not overconsume on operation costs to obtain the yield. The cost per metric ton for the three months of working operation is RM 9.76/ metric ton. Therefore, it can be assumed that the total cost for a year of operation is RM 47,444.24.

The allocation of inputs and their energy equivalence used in the production of the oil palm or FFB are shown in Table 5. The total input of energy for each month is in $\mathrm{MJha}^{-1}$. The yield of oil palm $\left(\mathrm{MJha}^{-1}\right)$ is estimated by determining the yield in kilogram which has been harvested each month and multiplied with $1.90 \mathrm{MJunit}^{-1}$. Then, the yield of oil palm was calculated in $\mathrm{MJha}^{-1}$. Next, the ratio of energy output and input is calculated

Table 5. Allocation input energy used for production of oil palm FFB

\begin{tabular}{|c|c|c|c|}
\hline Input energy source & June & July & August \\
\hline Labour $\left(\mathrm{MJha}^{-1}\right)$ & 1 & 1.07 & 0.92 \\
\hline Tractor grabber $\left(\mathrm{MJha}^{-1}\right)$ & 5.97 & 8.63 & 7.45 \\
\hline Fuel $\left(\mathrm{MJha}^{-1}\right)$ & 146.41 & 216.72 & 170.98 \\
\hline Total input energy $\left(\mathrm{MJha}^{-1}\right)$ & 153.38 & 226.42 & 179.35 \\
\hline $\begin{array}{l}\begin{array}{l}\text { Yield of oil palm } \\
\left(\mathrm{MJha}^{-1}\right)\end{array} \\
\end{array}$ & 1672 & 2470 & 2052 \\
\hline Ratio of energy output/input & 10.9 & 10.9 & 11.44 \\
\hline Energy productivity $\left(\mathrm{kgMJ}^{-1}\right)$ & 5.74 & 5.74 & 6 \\
\hline
\end{tabular}


by using Equation 11 to determine the ratio, then Equation 12 is used to calculate the energy productivity $\left(\mathrm{kgMJ}^{-1}\right)$ to determine the efficiency of energy utilization.

According to the yield per hectare, the total energy output in oil palm productivity in FELCRA BERHAD Kawasan Titi Gantong for each month was $1672 \mathrm{~kg} \mathrm{ha}^{-1}$, $2470 \mathrm{~kg} \mathrm{ha}^{-1}$ and $2052 \mathrm{~kg} \mathrm{ha}^{-1}$ respectively. The input energy is dominated by fuel, followed by machine and labour energy. The total of input energy for three months is $534.11 \mathrm{MJ}^{-1}, 22.05 \mathrm{MJ}^{-1}$ and $2.99 \mathrm{MJ}^{-1}$, for fuel, tractor grabber and labour, respectively.

The energy equivalent to producing the yield for each month is $153.38 \mathrm{MJha}^{-1}$, 226.42 $\mathrm{MJha}^{-1}$ and 179.35 $\mathrm{MJha}^{-1}$. Therefore, the energy productivity indicates that the amount of product is obtained from the unit area in return for the used energy amount is $5.74 \mathrm{kgMJ}^{-1}, 5.74$ $\mathrm{kgMJ}^{-1}$, and $6.0 \mathrm{kgMJ}^{-1}$ for each month respectively. In other means, for example in June, for $5.74 \mathrm{~kg}$ of produce, $1 \mathrm{MJ}$ of energy is used in the field. Averagely, every metric ton of FFB production will consume 124.73 MJ of input energy.

The energy efficiency is determined by the ratio of output energy to input energy. According to Internal Energy Agency (2016), they stated that something is more energy-efficient if it delivers more service for the same energy input or the same service for less energy input. The energy is used efficiently in the oil palm FFB production, an example was in June at 10.90. It shows that the oil palm production earned at least 10.90 times of the energy inputs given to the production process. Therefore, this can be concluded and considered as very energy-efficient on input energy.

\section{Conclusion}

In order to remain cost-competitive, the oil palm plantation sector needs to increase productivity even in times of labour shortage. Hence, the implementation of machinery especially in the most intensive process is imperative. The tractor grabber has been proven to be efficient in loading system and evacuation process of FFB. Based on the study, it has been estimated that the tractor grabber gives a positive impact on the total operation cost and energy usage. It shows the total cost of tractor operation is RM 11,861.06 for the three months and it can be assumed that the total cost for a year is about RM 47,444.26. Therefore, the cost per metric ton for a year is estimated at RM 9.76 and the total energy input for every metric ton is $124.73 \mathrm{MJ}$. In addition, this study depicts the mechanized grabber tractor was energy-efficient and worked effectively with a ratio of energy output of at least 10.90 times of energy input in the production process. Hence, this can contribute to the reduction of environmental pollution such as air and soil pollution.

\section{Conflict of interest}

The authors declare no conflict of interest.

\section{Acknowledgements}

Authors would like to thank FELCRA BERHAD Kawasan Titi Gantong, Bota, Perak for the cooperation to make this study successful.

\section{References}

Adip, M.E.B. and Pebrian, D.E. (2018). Performance comparisons of utilisation of silo and non-silo systems in mechanising fertiliser application in Malaysian oil palm plantation industry. International Journal of Industrial and Systems Engineering, 28 (4), 421-432. https://doi.org/10.1504/ IJISE.2018.090443

Awaludin, A., Salim, S.S.S., Abidin, A.H.Z. and Ngah, M.R. (2015). Performance study of an oil palm fresh fruit bunch three wheeler evacuation machine. Journal of Science and Technology, 5(2), 46-53.

Azwan, M.B., Norasikin, A.L., Abd Rahim, S., Norman, K. and Salmah, J. (2015). Analysis of energy utilisation in Malaysian oil palm mechanisation operation. Journal of Oil Palm Research, 28(4), 485495. https://doi.org/10.21894/jopr.2016.2804.10

Baran, M.F. and Gokdogan, O. (2016). Determination of energy balance of sugar beet production in Turkey: a case study of Kirklareli Province. Energy Efficiency, 9(2), 487-494. https://doi.org/10.1007/ s12053-015-9375-x

Bartzas, G. and Komnitsas, K. (2018). Energy flow analysis in agriculture; the case of irrigated pistachio production in Greece. Sustainable Energy Technologies and Assessments, 28, 73-80. https:// doi.org/10.1016/j.seta.2018.06.007

Biswas, B. (2017). Cropping system analysis for agricultural sustainability-productivity, economy, ecology and energy use efficiency. Journal of Experimental Biology and Agricultural Sciences, 5 (3), 12-19. https://doi.org/10.18006/2017.5 (3). 294.301

Fluck, R.C. (1991). Energy in farm production. Amsterdam: Elsevier Science.

Haryanto, B., Bukit, R.B., Situmeang, E.M., Christina, E.P. and Pandiangan, F. (2018). Study on Energy Productivity Ratio (EPR) at Palm Kernel Oil 
Processing Factory: Case Study on PT-X at Sumatera Utara Plantation. IOP Conference Series Materials Science and Engineering, Sumatera, 309, 012043). https://doi.org/10.1088/1757$899 X / 309 / 1 / 012043$

Internal Energy Agency. (2016). Retrieved from Energy Efficiency: http://www.iea.org/topics/ energgyefficiency

Ismail, A., Ahmad, S.M. and Sharudin, Z. (2013). The effect of labour shortage in the supply and demand of palm oil in Malaysia. Oil Palm Industry Economic Journal, 13(2), 15-26.

Mandal, K.S., Saha, K.P., Chosh, P.K., Hati, K.M. and Bandyopadhyay, K.K. (2002). Bioenergy and economic analyses of soybean-based crop production system in central India. Biomass Bioenergy, 23(5), 337-345. https://doi.org/10.1016/S0961-9534(02) 00058-2

Moerschner, J. and Gerowitt, B. (2000). Direct and indirect energy use in arable farming- An example on winter wheat in Northern Germany. In Weidama, B.P. and Meeusen, M.J.G. (Eds). Agricultural Data for Life Cycle Assessment, p. 195. Netherlands: Agricultural Economics Research Institute (LEI)

MPOB. (2014). Directory of Oil Palm Estates in Malaysia. MPOB, Bangi. Retrieved from MPOB website: http//www.mpob.com

Noor, R.S., Hussain, F., Umair, M., Farooq, M.U., Saad, A. and Sun, Y. (2020). Silage Corn Production Under Different Planting Methods in Rainfed Agriculture System: An Energy Analysis. Big Data in Agriculture (BDA), 2(1), 32-35. https:// doi.org/10.26480/bda.01.2020.32.35

Sharifi, M. (2018). Energy inputs-Yield relationship and cost analysis of melon production in Khorasan Razavi province of Iran. Engineering in Agriculture, Environment and Food, 11(3), 109-113. https:// doi.org/10.1016/j.eaef.2018.02.002

Singh, M.P., Pal, S.K., Thakur, R. and Vera, U.N. (1997). Energy input-output relationship of cropping system. Indian Journal of Agricultural Sciences, 67 (6), 262-264. 